\title{
THE EFFECT OF OPERATING CASH FLOW, NET PROFIT, ROA AND ROE ON STOCK RETURN OF IDX
}

\author{
Jessy Safitri Sitorus' ${ }^{1)}$, Ernika Br Siburian*2), Yosevin Simbolon ${ }^{3)}$, and Royto Enjelia br \\ Naibaho ${ }^{4)}$ \\ Universitas Prima Indonesia, Medan \\ sitorusjessy7@gmail.com ${ }^{1)}$, siburian.ernika@gmail.com ${ }^{2)}$, simbolonyosevin9@gmail.com ${ }^{3)}$, \\ roytoenjeliarf@gmail.com ${ }^{4)}$
}

\begin{abstract}
This research was conducted to determine the effect of Operating Cash Flow, ROA Net Profit and ROE on the movement of Stock Return, data or information obtained through financial statements. And the method of data collection is done with Purposive Sampling there are 21 companies in a period of 3 years, therefore the total sample of this study should be 63 samples. But because the data of this study using outliers then the total sample became 41. Then analyzed using multiple linear regression using SPSS 20 software. From this research, the researchers obtained results, namely: Operating Cash Flow, Net Income, and ROA individually had no significant effect on Stock Return. ROE individually affects and is significant to the Return of Shares. Operating Cash Flow, Net Income, ROA and ROE are simultaneously concurrently and significantly impacted on Stock Return. Keywords: Operating Cash Flow, Net Income, Return on Assets, Return on Equity, Share Return.
\end{abstract}

Keywords: Operating Cash Flow, Net Profit, ROA, ROE, Stock Return

*Corresponding author:

Email: siburian.ernika@gmail.com

DOI: https://doi.org/10.33369/j.akuntansi.11.2.189-196

\section{INTRODUCTION}

Currently the development of the manufacturing industry is quite rapid, this can be seen from the development of manufacturing companies registered in IDX every year more and more, then there is a possibility that this company is needed by the public and the prospects will be profitable in the present and future. Manufacturing companies on the Indonesia Stock Exchange cover various sectors and sub-sectors, including the Consumer Goods Industry Sector which is in great demand among investors because the share price of each company in this sector is more often increased which causes the return on its shares is also high. One of the things that affects the Consumer Goods Industry sector has a good share price is because companies in this sector are producers of goods that people need in their daily needs, such as food, beverages, medicines, beauty tools, etc. And it is expected that companies in this sector will experience an increase in the future. But it does not close the possibility also the share price of consumer goods industry companies experienced instability.

The capital market is currently very rapid and has an impact on the Indonesian economy. This is due to the increasing public interest to invest in the capital market, the growing public knowledge about the capital market, the growing number of companies listed in the capital market, and government support through investment policies. The development of capital market in Indonesia provides evidence that the capital market is an alternative investment for the people of Indonesia.

Share return is obtained from the profit obtained by investors against investments in a company. With the increasing level of profit earned, this proves that the company's ability to provide a rate of return on shares is very good and it gives good value to the company. 
THE EFFECT OF OPERATING CASH FLOW, NET PROFIT, ROA AND ROE ON STOCK RETURN OF IDX Jessy Safitri Sitorus, S.Pd., M.Pd. ${ }^{1)}$, Ernika Br Siburian ${ }^{2)}$, Yosevin Simbolon ${ }^{3)}$, and Royto Enjelia br Naibaho ${ }^{4)}$

Table 1. Phenomenon

\begin{tabular}{lccccc}
\hline $\begin{array}{l}\text { Issuer } \\
\text { Code }\end{array}$ & Year & Total Assets & Net Profit & $\begin{array}{c}\text { Operating Cash } \\
\text { Flow }\end{array}$ & Total Equity \\
\hline CINT & 2017 & $476,577,841,605$ & $29,648,261,092$ & $33,220,121,814$ & $382,273,759,946$ \\
\hline & 2018 & $491,382,035,136$ & $13,554,152,161$ & $(9,774,374,433)$ & $388,678,577,828$ \\
\hline GGRM & 2019 & $521,493,784,876$ & $7,221,065,916$ & $1,955,633,127$ & $389,671,404,669$ \\
\hline & 2017 & $66,59,930$, & $7,755,347$ & $8,204,579$ & $42,187,664$ \\
\hline UNVR & 2018 & $62,951,634$ & $7,793,068$ & $11,224,700$ & $45,133,285$ \\
\hline & 2019 & $78,647,274$ & $10,880,704$ & $11,174,403$ & $78,647,274$ \\
\hline & 2017 & $18,906,413$ & $7,004,562$ & $7,059,862$ & $5,173,388$ \\
\hline
\end{tabular}

Source : IDX

In Table 1 above, it is known that total assets from PT Chitose Internasional Tbk in 2018-2019 increased by $6.12 \%$ as well as total equity which increased by $0.25 \%$. In the data of Net Profit of Gudang Garam Tbk company in 2018-2019 increased by 39.62\% but in the data of Operating Cash Flow decreased by $0.24 \%$. In total assets of PT Unilever Indonesia Tbk in 2017-2018 increased by 3.26\% and in Operating Cash Flow increased by $12.10 \%$.

According to Sinaga (2010) if the total cash flow of operations is large then investors are more confident in the company because the higher the expected return value of shares given. However, if the total operating cash flow is not high then the level of investor confidence is also low for the company because it affects the expected value of the low return. According to Sandra Diana et al (2019:75) total operating cash flow has an impact on the return of shares, and shows that the value of the company's operating cash flow is good then the return on the resulting shares will also be good. Erina Putri Rachmawati research (2017) said operating cash flow does not affect the return of shares significantly, meaning this research does not agree with the theory that if the value of large operating cash flow means the interest of investors in investing is also greater because it is considered to get a positive return on shares. It is likely that this is an abnormal social, political and economic situation and has negative consequences for the return of shares by investors.

According to Putu, Made (2014) increased net profit can explain that a company managed to develop its management capabilities that have a positive impact for investors. Thus, if the value of profit earned is large, it will affect the increase in the share price and the return of the shares obtained also rises. According to Siti Aminah, H. Noor Shodiq Ask and Junaidi (2017) Accounting profit is useful to know the company's ability to predict the profit earned in investing. If the company earns a high enough profit then the investor will be interested in investing, because it will get a positive return on shares. According to Siti Aminah, H. Noor Shodiq Ask and Junaidi (2017) accounting profit is useful to know the company's ability to predict the profit earned in investing. If the company earns a high enough profit then the investor will be interested in investing, because it will get a positive return on shares. The above theory agrees with the results of research Januar Eko Prasetio (2003), Evi Mutia (2012), Nico Alexander and Nicken Destriana (2013). However, contrary to the results obtained by Haris Kristanto and Sumani (2015) obtained the results of the study that there was no significant impact of net profit on the return of shares.

Tandelilin (2010:315) argues that the value of ROA has an impact on the return of shares, because ROA is able to show the return on profit obtained by the company from the results of investment made by investors and serves to explain the company's performance in managing assets and obtaining profits. According to Kasmir (2012:202) said that the higher the total ROA means the company's performance in both managing assets to make a profit and increasing the value of Return on Assets profitability will affect the return on shares earned. The basis of the above theory agrees with the results of research lutfi, et al (2016) and Bukit 
(2013) which states roa affects the return of shares positively and significantly. However, in contrast to Wahyuhani (2013) and Simanjutak theory, Pibrianti D.L (2014) argues that ROA does not affect stock returns, because this ratio serves in knowing management's performance in obtaining net profit from asset usage.

Kurniawan, John. Jhony. (2013) argues that if the value of ROE is large, then it is proven that the company's management performance is good and it has an impact on the increasing desire of investors in investing. Husnan \&Pudjiastuti (2015) The market will receive information on the increase in Return on Equity as a sign that it is a good input for investors in making investments. This suggests that returns on invested shares will also increase. According to Neni, Kharis, Rita (2016), Stefanus Antara (2014) said that ROE has a positive impact on stock returns, it shows that the above theory is in line with the results obtained. However, according to Febriono (2016) ROE does not have a positive and significant impact on stock returns, so this study does not agree with the above theory.

The purpose of this study is to know the effect of operating cash flow on the return of shares partially, to know the effect of net income on the return of shares partially, to know the influence of ROA on the return of shares partially, and to know the influence of ROE on the return of shares partially. To determine the effect of operating cash flow, net income, ROA and ROE on Share Return simultaneously in IDX.

\section{RESEARCH METHODS}

This research is applied to the Indonesia Stock Exchange (IDX) obtained through www.idx.co.id and the type of research is Associative and the method applied is quantitative method. The research population is manufacturing companies in the Consumer Goods Industry Sector in the IDX period 2017-2019. Samples are obtained through Purposive Sampling method. The criteria taken are:

1) Consumer Goods Industry Sector Manufacturing Company that publishes financial statements in order 2017-2019.

2) Industrial Manufacturing Company of Consumer Goods that gained a positive net profit.

3) Industrial Manufacturing Company of Consumer Goods which has complete share price data.

Table 2. Sampling Criteria

\begin{tabular}{lc}
\hline Information & Amount \\
\hline Consumer Goods Industry Sector Companies listed on the IDX for the 2017-2019 period & 6 \\
\hline $\begin{array}{l}\text { UnpublishedConsumerGoods Industry SectorCompaniesconsecutivefinancial } \\
\text { statementsforthe 2017-2019 period }\end{array}$ & $(25)$ \\
\hline ConsumerGoods Industry SectorCompaniesthathavenegativeprofit & $(11)$ \\
\hline Companiesthatdo not havecomplete share price data & $(4)$ \\
\hline Numberofcompanies x Period21x3years & $(63)$ \\
\hline The numberofcompaniesthatbecamethesample & \\
\hline
\end{tabular}

\section{1) Operating Cash Flow}

PSAK No. 2 (2015) Operating Cash Flow is a major revenue activity for the company. Meanwhile, Ardiyos (2013) argues that Operating Cash Flow is a profit earned before interest and depreciation is reduced by tax. Operating Cash Flow Indicators (Hartono, 2013) are as follows:

$$
\mathrm{AKO}=\frac{\mathrm{AKO}_{\mathrm{t}}-\mathrm{AKO}_{\mathrm{t}-1}}{\mathrm{AKO}_{\mathrm{t}-1}}
$$

\section{2) Net Income}


Wild and Subramanyam (2014:25) argue that net profit signifies the profitability of the company. Profit represents a return to investors in the current year and the data on the financial statements explain the process of earning a profit. Stice and Skousen (2010:241) argue that net income is a profit earned after tax. Net income is diverted into estimated retained earnings. The indicators (Stice dan Skousen, 2010:241) are as follows:

Laba Bersih $=$ Laba - Beban Pajak

Sumber :

\section{3) Return on Assets}

Harahap (2013:305) states that ROA is a ratio that describes asset turnover as assessed from the company's volume. ROA is useful in the company's performance in managing assets and earning profits (Eduardus Tandelilin 2010:372). The indicators (Kasmir, 2012:202) of Return on Assets are as follows:

$$
\text { ROA }=\frac{\text { Laba Bersih setelah Pajak }}{\text { Total Aktiva }}
$$

\section{4) Return on Equity}

ROE is obtained from the profit on equity or the turnover of total assets that explains the company's performance in managing its resources in order to obtain a profit from equity (Fahmi, Irham 2014: 83). Kasmir (2012:204) argues that ROE is a useful ratio of knowing net profit after tax divided by total equity alone.

$$
\text { ROE }=\frac{\text { Laba Bersih setelah Pajak }}{\text { Total Ekuitas }}
$$

\section{5) Share Return}

Share Return (Tandelilin, 2010) is a driving force for investors in investing in return for the courage of investors and responsible for the investment made. Meanwhile, according to Ang (2010) Share Return is the level of profit received by investors for investments made in a company. The indicators (Hermuningsih, 2012) are as follows:

$$
\mathrm{R}_{\mathrm{it}}=\frac{\left(\mathrm{P}_{\mathrm{it}}-\mathrm{P}_{\mathrm{it}-1}\right)}{\mathrm{P}_{\mathrm{it}-1}}
$$

Hypothesis testing in this study using multiple linear regression analysis with the following equation:

$\mathrm{Y}=a+B_{1} X_{1}+B_{2} X_{2}+B_{3} X_{3}+e$

\section{RESULTS AND DISCUSION}

The data used in this research is data obtained from the financial statements of industrial manufacturing companies in the consumer goods industry period 2017-2019 obtained from IDX. The number of samples obtained is as many as 63, but because this study uses Outlier on

\begin{tabular}{|c|c|c|c|c|}
\hline $\mathrm{N}$ & Minimum & Maximum & Mean & Standard Deviation \\
\hline
\end{tabular}
SPSS 20, the number of sambel reduced to 41 samples.

\section{Table 3. Descriptive Statistics}




\begin{tabular}{lrrrrr}
\hline $\mathrm{X} 1$ & 41 & -892 & 1287 & 69.1002 & 481.17748 \\
\hline $\mathrm{X} 2$ & 41 & 7221065916 & 5360029000000 & 726099531068.6586 & 1231076515327.38040 \\
\hline $\mathrm{X} 3$ & 41 & 4 & 416 & 108.5366 & 86.69518 \\
\hline $\mathrm{X} 4$ & 41 & 9 & 264 & 132.0000 & 72.23988 \\
\hline $\mathrm{Y}$ & 41 & -363 & 538 & 63.4634 & \\
\hline Valid & 41 & & & & \\
N(list & & & & & \\
wise) & & & & & \\
\hline
\end{tabular}

Source : Output SPSS 2020

From the table above obtained the following results:

1. Variable $\mathrm{X}_{1}$ is operating cash flow with a total of $\mathrm{N}$ as much as 41 , has the smallest value -892 and the largest value of 1287 , and obtained mean of 69.1002 and standart deviation of 481.17748.

2. Variable $\mathrm{X}_{2}$ is a Return on Assets (ROA) with a total of $\mathrm{N}$ as much as 41 , has the smallest value of 4 and the largest value of 416, so it obtained a mean of 108.5366 and a standard deviation of 86.69518 .

3. Variable $\mathrm{X}_{3}$ is Return on Equity (ROE) with a total of $\mathrm{N}$ as much as 41 , has the smallest value of 9 and the largest value of 264 so that the mean is obtained by 132 and standart deviation of 72.23988 .

4. Variable $\mathrm{Y}$ is a Return of Shares with a total of $\mathrm{N}$ as much as 41 , has a small value of -363 and the largest value of 538, so it obtained a mean of 63.4634 and a standard deviation of 205.59729 .

Tabel 4. Classics Assumption

\begin{tabular}{cccc}
\hline \multirow{2}{*}{ Model } & Unstandardized & Coefficients & Standardized Coefficients \\
\cline { 2 - 4 } & $\mathrm{B}$ & Sig & Beta \\
\hline (Constant) & -114.324 & .040 & \\
\hline $\mathrm{X} 1$ & .021 & .215 & .049 \\
\hline $\mathrm{X} 2$ & -6.843 & .199 & -.041 \\
\hline $\mathrm{X} 3$ & -.049 & .830 & -.021 \\
\hline $\mathrm{X} 4$ & 1.413 & .171 & .497 \\
\hline
\end{tabular}

a. Dependent Variable: Y

Source: Output SPSS 2020

Judging from the table above each variable has a significant value above 0.05 , namely $\mathrm{X}_{1}$ of $0.215, \mathrm{X}_{2}$ of $0.199, \mathrm{X}_{3}$ of 0.830 and $\mathrm{X}_{4}$ of 0.171 . So the conclusion in this study is that there is no heteroskedastisitas. The regression model obtained from the table above is:

$\mathrm{Y}=-114,324+0,021 \mathrm{X} 1-6,843 \mathrm{X} 2-0,049 \mathrm{X} 3+1,413 \mathrm{X} 4$

Therefore, it can be explained that The Constant Value of the table above shows that the constant influence on Stock Return obtains a negative value, if there is an increase in the independent variable then there is a decrease in the Stock Return of $-114,324$. Variable $X_{1}$ a regression coefficient value of 0.021 meaning that each increase in operating cash flow of 1 unit will increase in Stock Return by 0.021 . Variable $\mathrm{X}_{2}$ has a regression coefficient value of 6,843 meaning that each increase in net profit of 1 unit will decrease in Return of Shares 6,843 . Variable $\mathrm{X}_{3}$ has a coefficient of tregresi value of -0.049 meaning that each increase in Return on Assets 1 unit will decrease on the Return of Shares -0.049 . Variable $\mathrm{X}_{4}$ has a coefficient value of 1.413 meaning that for each increase in ROE 1 unit will experience a decrease in the Return of Shares of 1,413. 
THE EFFECT OF OPERATING CASH FLOW, NET PROFIT, ROA AND ROE ON STOCK RETURN OF IDX Jessy Safitri Sitorus, S.Pd., M.Pd. ${ }^{1)}$, Ernika Br Siburian ${ }^{2)}$, Yosevin Simbolon ${ }^{3)}$, and Royto Enjelia br Naibaho ${ }^{4)}$

Table 5. Determination Coefficient Test

\begin{tabular}{lcccc}
\hline \multicolumn{4}{c}{ Model Summary } \\
\hline Model & $\mathrm{R}$ & $\mathrm{R}$ Square & Adjusted R Square & $\begin{array}{c}\text { Std. Error of the } \\
\text { Estimate }\end{array}$ \\
\hline 1 & $.308^{\mathrm{a}}$ & .095 & -.005 & 144.13640 \\
\hline
\end{tabular}

a. Predictors: (Constant), X4, X1, X2, X3

From the table above the value of $\mathrm{R}$ Square is 0.095 meaning that $9.5 \%$ variation of Stock Return is influenced by Operating Cash Flow, Net Income, ROA and ROE and influenced by other variables that are not included in this equation by $90.5 \%$.

Table 6. F Test

\begin{tabular}{|c|c|c|c|c|c|}
\hline \multicolumn{6}{|c|}{ ANOVA $^{\mathrm{a}}$} \\
\hline Model & & Df & Mean Square & F & Sig. \\
\hline \multirow{3}{*}{1} & Regression & 4 & 100242.571 & 2.798 & $.040^{\mathrm{b}}$ \\
\hline & Residual & 36 & 35829.164 & & \\
\hline & Total & 40 & & & \\
\hline \multicolumn{6}{|c|}{ a. Dependent Variable: Y } \\
\hline \multicolumn{6}{|c|}{ b. Predictors: (Constant), X4, X1, X2, X3 } \\
\hline
\end{tabular}

From the table above there is a simultaneous signification test value (F-test) which is $F_{\text {account }}$ of 2,798 At the free degree $1(\mathrm{df} 1)=4$, and a free degree of $2(\mathrm{df} 2)=36$, a $F_{\text {table }}$ value with a significant 0.040 of 2.60 and a value $F_{\text {account }}=2,798$ and $F_{\text {table }},=2.60$ at a significant of 0.040 . Due to its significant profitability of $0.040<0.05$ so Ha is accepted simultaneously. Operating Cash Flow, Net Income, ROA and ROE have an impact on Stock Return.

Table 7. T Test

\begin{tabular}{|c|c|c|c|c|c|c|}
\hline \multicolumn{7}{|c|}{ Coefficients $^{\mathrm{a}}$} \\
\hline \multirow{2}{*}{\multicolumn{2}{|c|}{ Model }} & \multicolumn{2}{|c|}{ Unstandardized Coefficients } & \multirow{2}{*}{$\begin{array}{c}\text { Standardized } \\
\text { Coefficients } \\
\text { Beta }\end{array}$} & \multirow[t]{2}{*}{$\mathrm{T}$} & \multirow[t]{2}{*}{ Sig. } \\
\hline & & B & Std. Error & & & \\
\hline \multirow{5}{*}{1} & (Constant) & -114.324 & 64.254 & & -1.779 & .084 \\
\hline & $\mathrm{X} 1$ & .021 & .066 & .049 & .322 & .749 \\
\hline & $\mathrm{X} 2$ & -6.843 & .000 & -.041 & -.255 & .800 \\
\hline & $\mathrm{X} 3$ & -.049 & .424 & -.021 & -.115 & .909 \\
\hline & $\mathrm{X} 4$ & 1.413 & .566 & .497 & 2.498 & .017 \\
\hline
\end{tabular}

a. Dependent Variable: $\mathrm{Y}$

From the results of the hypothesis test significance of the variable $X_{1}$, meaning Ha rejected but Ho accepted so partially no effect of operating cash flow on the Return of Shares. In conclusion, if the value of Operating Cash Flow increases or decreases then the Return of Shares does not increase. The situation agrees with Erina's research (2017) saying that Operating Cash Flow has no effect on Stock Return. In contrast to Haryati's theory (2016) which says Operating Cash Flow affects Stock Return.

In variable $\mathrm{X}_{2}$ is known significance test meaning $\mathrm{H}_{\mathrm{a}}$ is rejected and $\mathrm{H}_{0}$ is accepted so partially there is no effect of Net Income on Stock Return. It can be concluded that if the value of Net Profit increases or decreases, it will not affect the Return of Shares. This is in agreement with Utomo's research (2013) which said the amount of Net Income has no effect on The Return of Shares. On the contrary, Junaidi's research stated that Net Income has an effect on Stock Return. 
In variable $\mathrm{X}_{3}$ is known significance level meaning $\mathrm{H}_{\mathrm{a}}$ is rejected and $\mathrm{H}_{0}$ is accepted so partially ROA has no effect on Stock Return. It can be concluded that if the value of ROA increases or decreases, it does not affect the Return of Shares. This is in agreement with Purnamasari's research (2017) as explained that total Return on Assets has no effect on Stock Return. However, he disagreed with Fitri's research, Supriyanto, Andini (2017) who said Return on Assets had an effect on Stock Return.

In variable $\mathrm{X}_{4}$ is known significance level meaning $\mathrm{H}_{\mathrm{a}}$ is accepted and $\mathrm{H}_{0}$ is rejected so partially roe be influential and significant to the Return of Shares. It can be concluded that if the value of ROE increases or decreases it does not affect the Return of Shares. This is in agreement with Handyansyah's research; Lestari suggested that ROE influenced the Return of Shares. However, nurfalah's theory (2019) revealed that ROE has no effect on Stock Return.

\section{CONCLUSIONS AND SUGGESTIONS}

Based on the results of this study, it can be concluded that operating cash flow is partially insignificant and insignificant to the return of shares. Net Income is partially insignificant and insignificant to the Return of Shares. Return on Assets is partially insignificant and insignificant to stock returns. Return on Equity is partially and significantly influential on Stock Return. And simultaneously Operating Cash Flow, Net Income, Return on Assets and Return on Equity have an effect and significant effect on The Return of Shares. The advice that can be conveyed is for academics to be more thorough in conducting research so that the results obtained more accurately as an increase in knowledge in the field of accountants specifically on the return of shares. For companies to pay more attention to the stability of the company, observe economic developments, as well as financial performance, so that investors can assess and trust the company more in making investment decisions. For investors, investors expect the results of this study to be useful in decision-making in investing specifically for industrial manufacturing companies in the consumer goods industry in order to obtain the return on shares as expected. And for the next reviewer is expected to add variables and periods and samples of companies in order to obtain maximum results.

\section{REFERENCE}

Aminah siti, H. Noor Shodiq Ask Dan Jniadi. 2017. pengaruh laba bersih dan arus kas terhapad return saham pada perusahaan manufaktur yang terdaftar dalam bursa efek Indonesia. Jurnal Akuntansi Vol.6, No. 08 juni 2017 Universitas Islam Malang. http://riset.unisma.ac.id/index.php/jra/article/view/373

Ang, Robert. 2010. Buku Pintar Pasar Modal Indonesia. Jakarta : Media Soft Indonesia.

Ardiyos. 2013. Kamus Besar Akuntansi. Bandung : Alfabet

Fahmi, Irham.(2014). Analisis Kinerja Keuangan. Bandung : Alfabeta

Harahap, sofyan syafri. 2013. Analisa kritis atas laporan keuangan. Jakarta: PT Raja Grafindo Persada.

Harga Saham http://M.id.investing.com

Hartono, j, (2013). Teori Portofolio dan Analisis Investasi, EdisiKedelapan. BEPFE.

Hermuningsih, Sri. 2012. Pengantar Pasar Modal Indonesia. Yogyakarta : UPP STIM YKPN. https://journal.uii.ac.id/JSB/article/view/3304

Husnan, S \& Pudjiastuti. (2006). Dasar - Dasar Manajemen Keuangan. Edisi Kelima. Yogyakarta. UPP AMP YKPN. 
THE EFFECT OF OPERATING CASH FLOW, NET PROFIT, ROA AND ROE ON STOCK RETURN OF IDX

Jessy Safitri Sitorus, S.Pd., M.Pd. ${ }^{1)}$, Ernika Br Siburian ${ }^{2)}$, Yosevin Simbolon ${ }^{3)}$, and Royto Enjelia br Naibaho ${ }^{4)}$

IDX www.idx.co.id

Ikatan Akuntasi Indonesia. PSAK No. 2 Tentang Laporan Arus Kas-edisi revisi 2015. Penerbit Dewan Standar Akuntansi Keuangan : PT Raja Grafindo.

Kasmir. 2012.Analisis Laporan Keuangan. PT.Raja Grafindo Persada. Jakarta.

Nurfalah Retno Dwi. (2019) Pengaruh Earning Per Share (EPS), dan Return On Equity (ROE), Terhadap Return Saham. Jurnal Akuntansi.Universitas Islam Negeri Raden Intan, Lampunghttps://www.google.com/url?sa=t\&source=web\&rct=j\&url=http://repositor y.radenintan.ac.id/8075/\&ved=2ahUKEwi4ibjEwOnwAhUa7XMBHQ88BpoQFjAA egQIBBAC\&usg=AOvVaw0aekFIJYYzPTIq62NP_6K8

Rachmawati,ernia putri.2017. pengaruh laba bersih dan arus kas terhadap return saham pada perusahaan manufaktur yang terdaftar di bursa efek indonesia (bei) periode 2013-2015. Skripsi. Kendiri Vol 01, No. 11, 2017 Universitas Nusantara PGRI Kendiri. http://simki.unpkediri.ac.id/mahasiswa/file_artikel/2017/38fd4b2b22213fd2a7eb7a4af cd01aad.pdf

Stice, Stice, Skousen. 2010 Akuntansi keuangan, Buku I edisi 16. PT Raja Jakarta: Grafindo Persada

Tandelilin, Eduardus. 2010. Portofolio dan Investasi Teori dan Aplikasi. Edisi pertama. Yogyakarta Kanisius

Utomo Seno Jodi. 2011.Analisis Pengaruh Arus Kas Operasi dan Laba Akuntansi Terhadap Return Saham Perusahaan Manufaktur di Bursa Efek Indonesia.Jurnal Akuntansi, Universitas Negeri Semaranghttps://lib.unnes.ac.id/1512/1/7095.pdf 